\title{
STUDY OF THE COMPOSITION OF CRYOPROTECTOR AND TECHNOLOGICAL REGIME IN LIOPHILIZATION OF LIPOSOMES WITH OXALIPLATINUM
}

\author{
(C) A. Stadnichenko, Y. Krasnopolsky, T. Yarnykh
}

Ліофілізація є одним із найбільш перспективних та технологічних методів для зберігання структури нанобіотехнологічних продуктів. Ліпосоми із оксаліплатином були отримані, $і$ був проведений скрінінговий експеримент для дослідження оптимального кріопротектору.

Ціль. Отримання ліпосом із оксаліплатином, визначення типу кріопротектору, та його концентрації, дослідження параметрів ліофілізації для отримання продукта із максимальною інкапсуляцією оксаліплатина, із збереженням розміру ліпосом у нанодіапазоні, та оптимальним вмістом води у ліофілізаті.

Методи: Ліофілізащія була проведена на ліофільній сущщі Quгсо (КНР). Ліпосомальна форма оксаліплатину була отримана методом «пасивної» інкапсуляиії у комбінації із методом іонної сорбиії.

Результати: Лактоза, иукроза, мальтоза та трегалоза дигідрат були дослідженні у якості кріопротектантів. При цьому, трегалоза дигідрат виявився найбільш перспективним. Його оптимальною концінтрацією біло визнано 8 \% масових. Програма ліпосомальної сушки була оптимізована. Первинна сушка тривалістю 1740 хвилин була визнана недостатньою. Після изього програму відкоректували на 300 хв у сторону збільшення, до тривалості 2040 хв. Значення втрати інкапсуляиії склало $8 \%$, з $65 \%$ перед сушкою, до 57 \% після сушки. Що є високим показником, який свідчить про ефективність кріопротектанту та раціональну програму сушки. Розмір ліпосом після сушки склав 112 нм, остаточний вміст вологи, виміряний за методо К.Фішера склав 2,3\%, щзо є у межах иільового діапазону.

Висновки: Технологія для отримання ліпосомального оксаліплатину була запропонована. Поруч з циим був проведений скрінінговий експеримент по дослідженню оптимального кріопротектору. Найбільш перспективним було показано трегалозу дигідрат у якості кріопротектору. Було вивчено вплив різного вмісту трегалози дигідрату на ступень інкапсуляиії. Було показано, щуо оптимальним є вміст $8 \%$ за массою.

Було розроблено технологічні параметри процесу ліофілізації ліпосом із оксаліплатином: час сушки та температуру ліофілізації. Втрата ступеню інкапсуляиї оксаліплатину у ліпосоми не перевищувала 8 \%, із вмістом остаточної вологи 2,3%. Розмір ліпосом після прочесу залишався у нанодиапазоні та складав 112 нм

Ключові слова: Оксаліплатин, ліпосоми, екструзія під високим тиском, кріопротектор, ліофільна сушка

\section{Introduction}

Liposomes, as modern drug delivery systems, have been studied for several decades [1]. Over 50 liposomal drugs are licensed, registered and intensively used in various pathological states. It is worth to admit a number of liposomal drugs in the world market with the volume of sales in millions of US dollars, such as AmbiSome (lyophilized liposome form of amphoterecin B), Myocet (liposomal form of doxorubicin hydrochloride), Visudine (liposomal form of verteporfin), Mepact (liposomal form of immunomodulator of mifamurtide). Another promising group of preparations, is one that contain platinum, in particular oxaliplatin, as well as preparations of the group of camptothecins, for example, irinotecan, which demonstrate efficacy both in monotherapy and in combination with other antitumor medicine [2]. In addition to being able to act as carriers of active pharmaceutical ingredients (API), liposomes possess a unique ability to reduce the toxic effect of cytostatics, which limits the full realization of their potential [3].

2. Formulation of the problem in a general way, the relevance of the theme and its connection with important scientific and practical issues

However, the chemical instability of some APIs in their aqueous solutions, the propensity of the phospholipid bilayer liposomes to oxidation, loss of encapsulation during storage make it difficult to develop liposomal drugs, limiting the launching of these drugs to the pharmaceutical market [4].
3. An analysis of the latest research and publications in which the solution of this problem has been initiated and on which the author relies

There is exists a number of methods for stabilization of liposomal drugs. The most promising, from technological point of view, is lyophilization method, which allows to preserve both, the native chemical structure of active and additional components, as well as the threedimensional structure of liposomes, even after rehydration process [5].

The lyophilization process is the sublimation of water from the preparation, transformation of water into vapor and its removal, excluding a liquid phase. The main components of the freeze drying system are a sample chamber, a condenser, a vacuum pump, a shelf temperature control system, and a condenser cooling system. The product to be lyophilized is placed in the sample chamber. With the help of the shelf cooling unit, the product is frozen to a temperature of " $-40 "{ }^{\circ} \mathrm{C}$. Condenser shelves, must be cooled to a temperature from " -75 " ${ }^{\circ} \mathrm{C}$ to $"-80 "{ }^{\circ} \mathrm{C}$. The chamber is sealed and with a vacuum pump, through the condenser, a pressure of about $0.03 \mathrm{~mm} \mathrm{Hg}$ is created. Below the triple point (for pure water: 6.1 mbar at $0{ }^{\circ} \mathrm{C}$ ) there are only a solid and gas phases for water. This physical principle is a base for the process of sublimation drying. Ice from the preparation, is sublimated at the temperature of the shelves, and turns into water vapor. At the same time, take place its mass transfer to the condenser chamber, where, at a lower 
temperature, it precipitates as ice on the condenser's shelves [6].

The sublimation process can be divided into two physical stages - sublimation of ice from the production and its capture by condenser shelves. The degree of water transfer, as well as the speed of the process is regulated by the temperature program of the shelves in product chamber and the total process time [7].

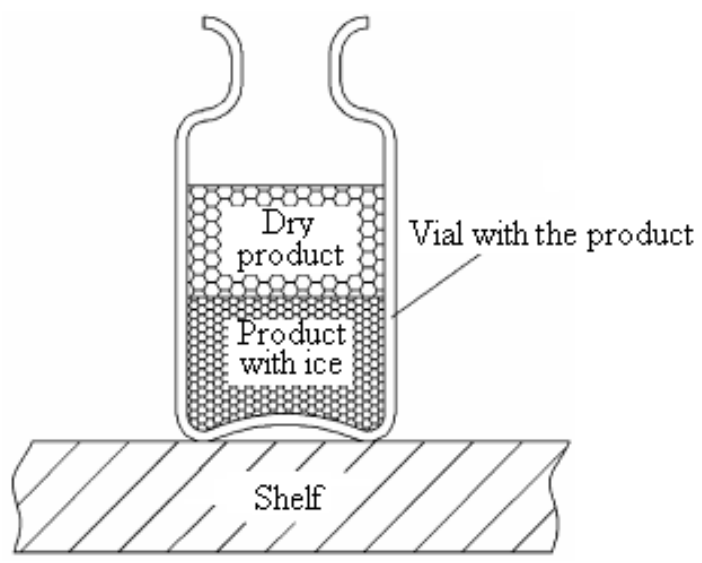

Fig. 1. Structure of the vial with a product during the drying process

In Fig. 1 showed the type of vial with the product during the primary drying process. Part of the ice, at the top of the vial, sublimated, opening the 3-D structure of the preparation, and in the same time, the process of evaporation in the lower part of the product takes place.

Three main technological stages of the lyophilization process can be distinguished: freezing, primary drying, in which most of the ice is removed, and secondary drying, when the bound and occlusal water is removed.

4. The selection of previously unsolved parts of the general problem, which is devoted to the article

The lyophilization process is characterized by a number of critical points - such as the total drying time, the secondary drying temperature, which should be higher than the melting point of the solvent being removed, but at the same time not destroy the matrix of nanoparticles. [8]. The most important stage in the development of liposomal drugs is the selection of a cryoprotectant, which in a dried preparation preserves the 3-D structure and prevents the collapse of the phospholipid bilayer.

5. Formulating the goals (objectives) of the article

The aims of the study - are to obtain liposomes with oxaliplatin; to determine the type of cryoprotectant and its concentration; to study lyophilization parameters to manufacture the product with maximum encapsulation parameters, along with remaining the size of liposomes in the nanoscale and with optimum residual moisture content.

6. Statement of the main research material (methods and objects) with justification of the results

For preparation of liposomes was purchased egg phosphatidylcholine from Lipoid, Germany. Cholesterol, citric acid monohydrate, trehalose dihydrate, solvents were purchased from Sigma-Aldrich, USA. The lipid film was prepared on a Buchi 210 rotary evaporator with a vacuum controller, at a residual pressure of 0.02 atm. For homogenization we used a high pressure extrusion method. The extrusion was carried out using a Microfluidiser M-110P model from Microfluidics, USA at a pressure of $1500 \mathrm{~atm}$. The size of the liposomes was determined at a temperature of $20^{\circ} \mathrm{C}$ on a Zetasizer Nano ZS, Malvern Instruments, UK. Ultrafiltration was carried out on a Minim2 model, PALL, USA. Lyophilization was carried out in the Quarco model, P.R.C. The residual water content was determined by K. Fisher's method, on a V-20 Mettler Toledo, USA. The encapsulation degree was determined by HPLC on a LC-20 instrument Shimadzu, Japan, according to a method developed earlier [9]. The preparation was sterile filtered and bottled in aseptic conditions in sterile vials VAT050-2C, $50 \mathrm{ml}$ capacity, manufactured by Schott, Germany.

Liposomal oxaliplatin was prepared by the method of "passive" encapsulation in combination with the method of ion sorption. Lipids: PC/Chol/DPPC in a ratio of 50/20/30 (by weight) was placed in a round-bottomed flask, dissolved in a chloroform-anhydrous ethanol mixture with short-term exposure to ultrasound (at $35 \mathrm{kHz}$ ) until the opalescence disappeared. The resulting lipid film was hydrated with a solution of oxaliplatin at a concentration of $4 \mathrm{mg} / \mathrm{ml}$ for 60 minutes at $20^{\circ} \mathrm{C}$.

Homogenization was carried out on a high pressure homogenizer until a liposomes with size of $80120 \mathrm{~nm}$ was obtained. The concentration of oxaliplatin in the obtained liposomes was adjusted by water for injection. In the final product, the concentration of oxaliplatin was $2 \mathrm{mg} / \mathrm{ml}$, the total lipid concentration was $20 \mathrm{mg} / \mathrm{ml}$.

A screening experiment was conducted to select the most prospective cryoprotectant for liposomal oxaliplatin. A 52-hour drying program was used. Encapsulation of oxaliplatin in liposomes before lyophilization was $62 \%$, the size of liposomes was $112 \mathrm{~nm}$. The results of the experiment are presented in Table 1.

Table 1

Results of the cryoprotectant study for lyophilization of liposomal oxaliplatin

\begin{tabular}{|l|l|c|c|c|c|}
\hline No. & \multicolumn{1}{|c|}{ Cryoprotectant } & $\begin{array}{c}\text { The oxaliplatin con- } \\
\text { centration of, mg/ml }\end{array}$ & $\begin{array}{c}\text { Size of } \\
\text { liposomes, nm }\end{array}$ & $\begin{array}{c}\text { Oxaliplatin } \\
\text { encapsulation, } \%\end{array}$ & $\begin{array}{c}\text { Water } \\
\text { content, } \%\end{array}$ \\
\hline 1 & Lactose monohydrate, 5\% & 2.0 & 116 & 42 & 0.8 \\
\hline 2 & Sucrose, 5\% & 2.0 & 110 & 37 & 0.7 \\
\hline 3 & Trehalose dihydrate, 5\% & 2.0 & 114 & 46 & 0.8 \\
\hline 4 & Maltose, 5\% & 2.0 & 112 & 35 & 0.5 \\
\hline
\end{tabular}


It can be seen from Table 1 that after use of different cryoprotectants and a 52-hour drying program, the encapsulation is reduced from $62 \%$ to $35-46 \%$, while the size of the liposomes remains practically unchanged. A low variance of the encapsulation meaning is explained by the loss of encapsulated oxaliplatin, while the ion-sorption capture mechanism operates with any type of cryoprotector [10]. The low content of residual water is explained by the high duration of the lyophilization process -52 hours (3120 $\mathrm{min}$ ).

The best result for the encapsulation of oxaliplatin into liposomes after lyophilization was observed with trehalose dihydrate as cryoprotectant. To study the effect of different cryoprotectant content on the degree of encapsulation and the size of liposomes, an experiment was carried out. The cryoprotectant was studied in concentrations of $4 \%, 6 \%, 8 \%, 10 \%$. Liposomes were prepared according to the previously described technology, a cry- oprotectant solution filtered through a polyethersulfone filter with a pore size of $0.22 \mu \mathrm{m}$ was added in the last step, with a final concentration of oxaliplatin of $2 \mathrm{mg} / \mathrm{ml}$ and a lipid concentration of $20 \mathrm{mg} / \mathrm{ml}$. The results of the experiment are shown in Fig. 2.

As can be seen from Fig. 2, the optimum concentration of the cryoprotectant is $80 \mathrm{mg} / \mathrm{ml}$ or $8 \%$. Also, was carried out an additional experiment to optimize the time of freeze-drying process. The 52-hour program, used in the screening experiments, showed residual water content of less than $0.8 \%$, what can be evidence for excessive duration of the process. So, on the next step was studied the process of lyophilization with duration of 29 hours (1740 minutes), similar to one that used in the lyophilization of liposomes with irinotecan [article in press].

In Fig. 3 are shown the results obtained during the process of lyophilization within 29 hours.

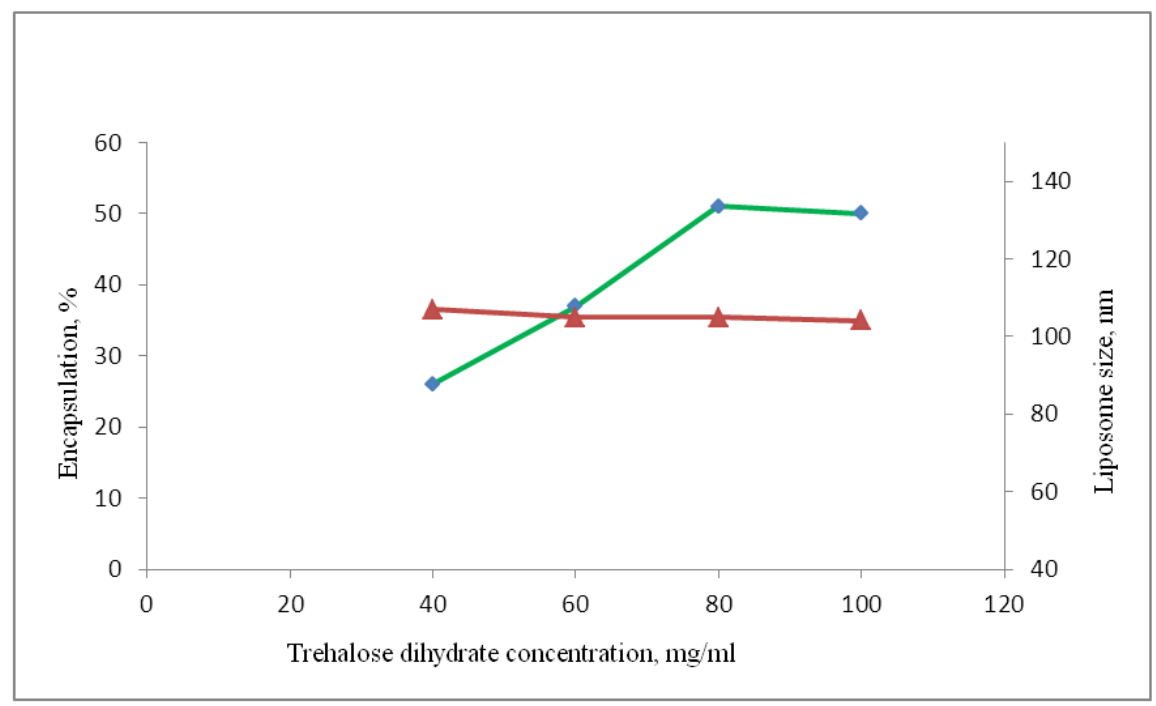

Fig. 2. Influence of trehalose dihydrate as a cryoprotector on encapsulation and the size of liposomes after lyophilization. $\boldsymbol{\Delta}-$ dependence of the liposome size from trehalose dihydrate content; - dependence of oxaliplatin encapsulation from concentration of trehalose dihydrate

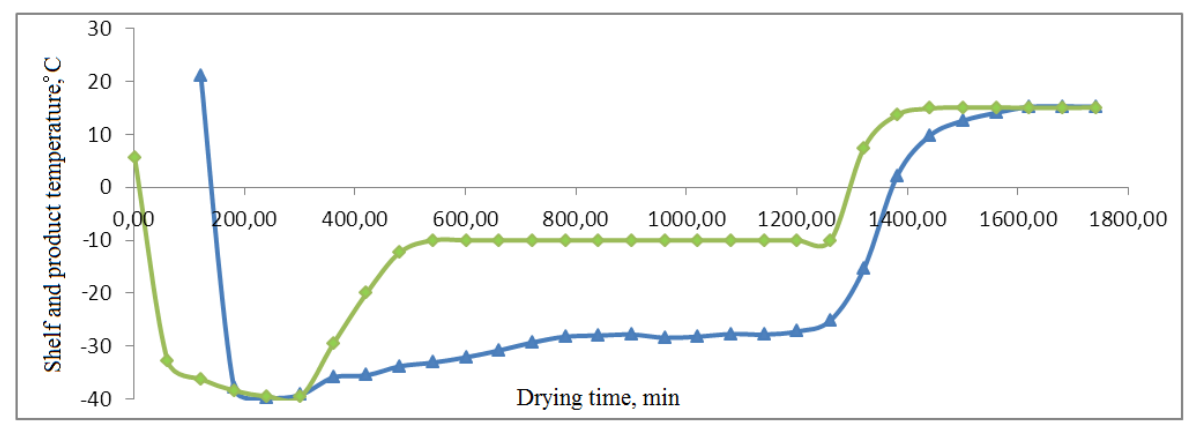

Fig. 3. Mode for lyophilization of liposomal oxaliplatin with a process duration in 28 hours: - temperature of the shelves of the chamber, $\boldsymbol{\Delta}$ - temperature of the product during the lyophilization process

After the use of the drying process of 29 hours it has been found that the residual water content is $7.4 \%$, what is out of specification limits. It can be seen from Fig. 3 that the temperature of the product in the vicinity of the 1300th minute do not reach the temperature of the shelves, which is evidence of the non-complete primary drying stage, and indicating the presence of residual water in the sample. After the end of the process, it was noted that the lyophilized mass had a "foamy" appear- ance, indicating that there was a significant amount of moisture in the stage of secondary drying. Differences in the technological parameters in compare to liposomal irinotecan can be explained by the presence in the lipid bilayer of liposomal oxaliplatin polar DPPG modifier, which effectively retains water, in comparison with the neutral membrane of liposomal irinotecan, and requires a longer drying process. Given that the primary drying time was not enough, the process of the program was 
adjusted. The secondary drying temperature remained unchanged and was $15^{\circ} \mathrm{C}$.

In Fig. 4 is shown the program of lyophilisation of the liposomal oxaliplatin, modified in view of the received data. The time of primary drying was increased on 300 minutes in comparison with the previous experiment. The total time of the process was 34 hours or 2040 minutes.
From Fig. 4 it can be seen that during the primary drying, the product temperature "smoothly" approaches the temperature of the shelves, which indicates the sublimation of the main content of residual water. Also, during the secondary drying, the temperature approaches the temperature of the shelves 4 hours before the end of the process, which indicates complete removal of water during the secondary drying.

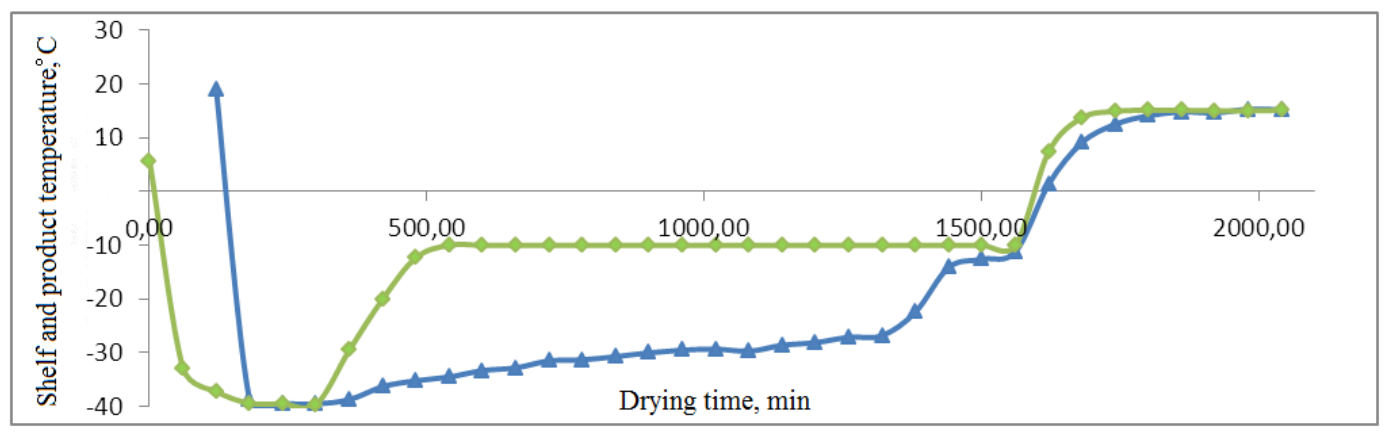

Fig. 4. Mode of freeze-drying liposomal oxaliplatin, with a total duration of 34 hours. - temperature of the shelves of the chamber, $\Delta$ - temperature of the product during the lyophilisation process

Liposome size, residual water content and encapsulation were measured. The size of liposomes was $112 \mathrm{~nm}$, the degree of encapsulation was $57 \%$, while taking into account that analogical values before lyophilization was $65 \%$, the loss was $8 \%$.

This is sufficiently high value, indicating an effectiveness of cryoprotectant and a rational program of lyophilization. The residual water content was $2.3 \%$.

\section{Conclusion}

1. A technology for obtaining liposomal oxaliplatin has been proposed and screening studies have been conducted to determine the cryoprotectant. It is proposed to use as a cryoprotector trehalose dihydrate as the most prospective. The effect of different concentrations of trehalose dihydrate on the degree of encapsulation of oxaliplatin in liposomes was studied. It was found that the optimum concentration of the cryoprotectant in the preparation is $8 \%$ (by mass).

2. The technological parameters for the process of liposomal oxaliplatin lyophilization were developed: the temperature of secondary drying, the time of secondary drying, the total time of the process.

The decrease in encapsulation of oxaliplatin in liposomes during lyophilization did not exceed $8.0 \%$ with a residual water content of about $2.3 \%$.

The size of the liposomes after lyophilization was $112 \mathrm{~nm}$.

\section{References}

1. Sharma, A. Liposomes in drug delivery: Progress and limitations [Text] / A. Sharma, U. S. Sharma // International Journal of Pharmaceutics. - 1997. - Vol. 154, Issue 2. - P. 123-140. doi: 10.1016/s0378-5173(97)00135-x

2. Bajetta, E. Efficacy of treatment with irinotecan and oxaliplatin combination in FU-resistant metastatic colorectal cancer patients [Text] / E. Bajetta, E. Beretta, M. D. Bartolomeo, D. Cortinovis, E. Ferrario, G. Dognini, L. Toffolatti et. al. // Oncology. 2004. - Vol. 66, Issue 2. - P. 132-137. doi: 10.1159/000077439

3. Shvets, V. I. Liposomyi v farmatsii. Produktyi nanobiotehnologii [Text] / V. I. Shvets, Yu. M. Krasnopolskiy // Provizor. 2008. - Vol. 3. - P. 18-24.

4. Torchilin, V. P. Liposomes: A Practical Approach [Text] / V. P. Torchilin, V. Weissig. - New York: Oxford University Press, 2003. $-384 \mathrm{p}$.

5. Chen, C. An overview of liposome lyophilization and its future potential [Text] / C. Chen, D. Han, C. Cai, X. Tang // Journal of Controlled Release. - 2010. - Vol. 142, Issue 3. - P. 299-311. doi: 10.1016/j.jconrel.2009.10.024

6. Wang, W. Issues in freeze drying of aqueous solutions [Text] / W. Wang, C. Mo, C. Guohua // Chinese Journal of Chemical Engineering. - 2012. - Vol. 20, Issue 3. - P. 551-559. doi: 10.1016/s1004-9541(11)60218-8

7. Franks, F. Freeze-Drying of Pharmaceutical and Biopharmaceuticals [Text] / F. Franks, T. Auffret. - London: RSC Publishing, 2007. - 206 p. doi: 10.1039/9781847557704

8. Chen, G. Role of freeze drying in nanotechnology [Text] / G. Chen, W. Wang // Drying Technology. - 2007. - Vol. 25, Issue 1. - P. 29-35. doi: 10.1080/07373930601161179

9. Stadnichenko, A. V. Razrabotka i validatsiya metodiki opredeleniya stepeni inkapsulyatsii irinotekana gidrohlorida v liposomyi [Text] / A. V. Stadnichenko, Yu. M. Krasnopolskiy, V. I. Shvets // Biofarmatsevticheskiy zhurnal. - 2015. - Vol. 7, Issue 1. P. 53-55.

10. Stadnichenko, O. V. Vivchennya vplivu zaryadu lipidnoyi membrani pri stvorenni liposom iz oksaliplatinom [Text] / O. V. Stadnichenko, Yu. M. Krasnopolskiy, T. G. Yarnih // Vistnik farmatsiyi. - 2016. - Vol. 4. - P. 34-37. 
Stadnychenko Alexander, $\mathrm{PhD}$, Department technology of drugs, National University of Pharmacy, Pushkinska str., 53, Kharkiv, Ukraine, 61002

Krasnopolskiy Yuriy, Doctor of Pharmaceutical Sciences, Professor, Department of Biotechnology, Biophysics and Analytical Chemistry, National Technical University «Kharkiv Politechnic Institute», Kyrpychova str., 2, Kharkiv, Ukraine, 61002

E-mail: biotech_ntu_khpi@ukr.net

Yarnykh Tatyana, Doctor of Pharmaceutical Sciences, Professor, Head of department, Department technology of drugs, National University of Pharmacy, Pushkinska str., 53, Kharkiv, Ukraine, 61002

E-mail: tl.@nuph.edu.ua

УДК 616.379-008.64:57.084:616.132:616.36

DOI: $10.15587 / 2519-4852.2017 .119490$

\title{
STUDY OF SUPEROXIDE- AND NO-DEPENDENT PROTECTIVE MECHANISMS OF N-ACETYLCYSTEINE AND LOSARTAN IN RAT'S AORTA AND LIVER UNDER STREPTOZOTICIN-INDUCED TYPE 1 DIABETES MELLITUS
}

\author{
(C) I. Sytnyk, A. Burlaka, A. Vovk, M. Khaitovych
}

Мета. Дослідити супероксид- та NO-залежні механізми дї N-ацетилцистеїну (NAC) та лозартану (LOS) в аорті та печіниі шурів із індукованим иукровим діабетом 1 типу (ЦД1).

Методи. Щури із індукованим ЦД1 отримували NAC (1,5 г/к2), LOS (20 мг/кг) або їх комбінацію (NAC+LOS) протягом 4-х тижнів.

Результати. Швидкість генерування СР мітохондріями аорти нелікованих тварин із ЦД1 була достовірно вищзю порівняно до групи контролю, в той час рівень NO знижувався. Продукція СP та NO значно підвищувалася у печінщі тварин із ЦД1. Підвищувалася екскречія з сечею маркеру окисного пошкодження ДНК -8-оксогуаніну у шурів із ЦД1. Всі досліджувані фармакологічні схеми сприяли достовірному зниженню швидкості генеруванні CP та NO мітохондріями аорти та печінки; рівень NO був значно нижчий у тканині печінці щурів порівняно із групою ЦД1. Тільки NAC статистично значуще відновлював рівень NO в аорті діабетичних щурів. Введення NAC/ LOS або NAC+LOS сприяло збільшенню рівня 8-оксогуаніну порівняно із групою ЦД1.

Висновки. Корекція NAC та LOS чи їх комбінації пов'язана із захистом клітин аорти та печінки у тварин із ЦД1 від токсичної дії СР, перешкоджаючи мітохондріальній дисфункиії і послідуючого руйнування ДНК, щзо свідчить про кардіопротекторні ефекти та загальне метаболічне покращення

Ключові слова: стрептозотоцин, супероксид, аорта, печінка, щури, $N$-ацетилцистеїн, лозартан

\section{Introduction}

Diabetes mellitus (DM) is the most widespread endocrinological disease, and its complications, especially diabetic cardiomyopathy (DC) decreases quality of patients' lives and often results in fatal outcome. According to the WHO's data, 2.2 million deaths induced by cardiovascular complications in case of excessive hyperglycemia were registered at the beginning of $2012[1,2]$.

2. Formulation of the problem in a general way, the relevance of the theme and its connection with important scientific and practical issues

One of the basic mechanisms of DC development is hyperglycemia-induced oxidative stress (OS) that includes excessive formation of reactive oxygen species (ROS) - superoxide radicals (SRs) as well as antioxidant system defense depletion. SRs have significant implication in the intracellular signaling and mediate various cellular functions, including activation of transcription factors, kinases and ion channels. Furthermore, increased generation of SRs initiates activation of 5 basic signaling ways including in the pathogenesis of diabetic complications, such as: polyol pathway, increased formation of advanced glycation end products (AGEs), elevated expression of the receptor for AGEs and its activating ligands; activation of protein kinase $\mathrm{C}$ (PKC) isoforms; hyperactivity of the hexamine pathway $[3,4]$.

Additionally, overproduction of SR initiate formation of the most aggressive hydroxyl radicals ( $\left.\mathrm{HO}^{\circ}\right)$ and reactive nitrogen species (RNS) in reaction with NO in form of toxic peroxynitrite $\mathrm{ONOO}^{-}$, especially under hypoxia condition [5].

3. Analysis of recent studies and publications in which a solution of the problem and which draws on the author

It has been proved that hyperglycemia-induced accumulation of mitochondrial ROS is associated with disturbance of transmembrane potential that directly induces opening of the mitochondrial pore and results in mitochondrial dysfunction and DC development [6]. Therefore, the search for new pharmacological schemes in DC treatment which minimize oxidative damage of cells has become an actual problem.

Lately, the effectiveness of synthetic antioxidant $\mathrm{N}$-acetylcysteine (NAC) for correction of cardiovascular 